Attila Tasnádi

\title{
The extent of the population paradox in the Hungarian electoral system
}

\author{
Attila Tasnádi \\ Department of Mathematics \\ Corvinus University of Budapest \\ attila.tasnadi@uni-corvinus.hu
}

August 6, 2007

Appeared in Public Choice 134(2008), 293-305.

CSpringer-Verlag ${ }^{1}$

\begin{abstract}
The Hungarian mixed-member electoral system, adopted in 1989, is one of the world's most complicated electoral systems, and, as this paper demonstrates, it suffers from the "population paradox." In particular, the governing coalition may lose as many as 8 seats either by getting more votes or by the opposition obtaining fewer votes on each territorial list.
\end{abstract}

Keywords: Population paradox; Hungary; Electoral systems; Mixed systems

\footnotetext{
${ }^{1}$ The original article is available at www.springerlink.com. DOI: $10.1007 / \mathrm{s} 11127-007-9228-\mathrm{z}$
} 


\section{Introduction}

The Hungarian electoral system has been extensively investigated by Benoit and Schiemann (2001), and by Benoit (2001), among others. This paper focuses on its apportionment of seats. Briefly, the 386 representatives get elected through 176 singlemember districts (SMDs). Proportional representation (PR) formulas determine the other 210 representatives from 20 territorial party lists (with a maximum of 152 seats) and a national party list (with at least 58 seats). Each territorial list as well as the national list has its own divisor for converting votes into seats.

In PR systems the so-called population paradox emerges if a party with a faster voter growth rate loses one or more seats to a party with a slower voter growth rate. From Balinski and Young (2001) we know that, under certain technical conditions, only divisor methods, which allot seats by dividing the votes of each party by an appropriately chosen common divisor and then applying a specific rounding rule, avoid the population paradox. Therefore, the Hungarian two-level apportionment procedure, by employing 21 distinct divisors, allows for the population paradox. However, Balinski and Young's theorem cannot be applied to the Hungarian two-ballot system, in which losing SMD votes on the national list are combined with correction votes coming from the 20 territorial lists. Tasnádi (2007) pointed out that the Hungarian apportionment procedure may suffer from the population paradox by showing that 10,000 additional votes for the largest governing party on the Budapest list can shift one seat from the largest governing party to the smallest opposition party. This paper investigates how many seats can be lost either by one party gaining votes or by its opponent losing votes on the territorial lists. This is of particular interest since, in the 2002 elections, the 
governing coalition had just four representatives more than necessary to form a government.

\section{The population paradox}

The population paradox was first observed in the United States in 1900 when, based on Hamilton's method, Maine could gain an additional seat at the expense of Virginia even though Virginia's population was growing faster than Maine's (Balinski and Young 2001:43). More generally, the population paradox emerges if a state with a faster population growth rate loses one or more seats to a state with a slower population growth rate. $^{2}$ In proportional representation systems, states and populations are analogous to parties and their votes, respectively. According to Balinski and Young (2001:117), only divisor methods avoid the population paradox.

The population paradox occurs when there is a non-monotonic relationship between the number of votes and the seats obtained by the parties. However, in plurality voting systems — as in the United States and the United Kingdom — the losing party can obtain even more votes than the winning party. The same observation is also valid for mixed-member electoral systems and could apply to some elections in Hungary. However, this type of non-monotonic relationship, since it is a consequence of incorporating SMDs into an election system, is not the subject of this paper. The kind of non-monotonicity investigated here does not serve any objective of the designers of

\footnotetext{
${ }^{2}$ The definition also allows for negative or zero growth rates.
} 
electoral systems, for the most part, but is just an avoidable byproduct of mixing or modifying several sound apportionment methods.

Before proceeding, the population paradox for multi-territorial and two-ballot systems needs to be defined. The entire territory is divided into territorial units using two (not necessarily different) methods: for example, the first division could determine the SMDs, and the second division could determine the units for the territorial party lists. However, other types of territorial divisions are allowed, so as not to exclude the electoral rule of the Welsh Assembly in which there are smaller territorial units for the first vote and larger territorial units for the second vote (see, for example, Altunbas and Chakravarty 2000). A multi-territorial two-ballot system is called population nonmonotonic if for each party, considering each territorial unit separately, either a ceteris paribus increase of its own votes or a ceteris paribus decrease of another party's votes can lead to a loss of seats. Since in many multi-party systems there may be a competition of coalitions (government versus opposition), potential coalitions are evaluated jointly. This type of monotonicity could be referred to as coalition population monotonicity; however, the term "coalition" is omitted for the sake of brevity. A nonpopulation-monotonic electoral system exhibits the so-called population paradox.

The population paradox has been documented for several mixed-member electoral systems, such as the electoral rule of the German Bundestag (see Fehndrich 1999) and the election of the Welsh Assembly (see Altunbas and Chakravarty 2000; Altunbas et al. 2002). While the German electoral rule was designed prior to Balinski and Young's (2001) theory (first published in a comprehensive book in 1982), the designers of more recent mixed-member electoral rules should have been aware of these results, and 
therefore should have been able to design electoral systems free of the population paradox.

\section{A hypothetical outcome of a Hungarian election}

Hungary is divided into 20 counties, each with a given number of territorial seats, and each county is divided into a given number of SMDs. Table 1 shows the seat distributions by county. Each voter has two votes: the first vote goes to a SMD candidate and the second vote to a territorial party list, where the SMDs are proper subsets of the territories. An assumption is that "split-ticket" voting does not occur (that is, each voter gives its SMD vote to that candidate who was nominated by the party chosen by its second vote), unless stated otherwise. Moreover, a national list was introduced to soften the winner-take-all effect in the SMDs by listing each party's nonwinning SMD candidates' votes on the national list (for each party passing the 5\% threshold). Since most of the territorial lists distribute only a small number of seats (up to 10 seats for 17 counties, see Table 1), a PR formula would leave small parties that pass the 5\% threshold without a seat. Therefore, the national list is also used to compensate parties for the highly non-proportional outcomes on the territorial lists. The

Location of Table 1 description of the compensation mechanism, which adds correction votes coming from the territorial lists to the votes coming from the SMDs, will be discussed later.

The analysis starts with the political geography and party alignment of the 2006 Hungarian election, and therefore describes the existence of two large parties, denoted by $\mathrm{A}$ and $\mathrm{C}$, with nationwide support of at least $40 \%$ of the votes; and two other parties, 
$\mathrm{B}$ and $\mathrm{D}$, passing the $5 \%$ threshold to qualify for seats from the territorial and national lists. Moreover, the governing coalition consisting of parties A and B seeks reelection, while parties $\mathrm{C}$ and $\mathrm{D}$ form the current opposition.

Parties $\mathrm{A}$ and $\mathrm{C}$ each win an equal number (88) of SMDs, so the territorial and national lists will decide the final outcome. For the sake of simplicity, party A wins all the SMDs in Budapest, Baranya, Borsod-Abaúj-Zemplén, Csongrád, Heves, JászNagykun-Szolnok, Komárom-Esztergom, and Szabolcs-Szatmár-Bereg, while party C wins all the SMDs in Bács-Kiskun, Békés, Fejér, Győr-Moson-Sopron, Hajdú-Bihar, Nográd, Pest, Somogy, Tolna, Vas, Veszprém, and Zala. This latter assumption simplifies the calculation of votes won by parties on the national list, since then the votes of a party coming from the SMDs on the national list (in the case of no "splitticket" voting) can be calculated by adding the party's second votes from those counties that the party lost.

The presentation of the allotment procedure of the Hungarian electoral system is incorporated in the examples, showing the possibility of a severe population paradox effect. A candidate wins a SMD by receiving a majority of votes in the first round or, alternatively, by receiving a plurality of votes in the second round. In any case, the firstround votes of those losing SMD candidates, whose party passes the 5\% threshold, will be added to the appropriate parties' votes on the national list.

For example, the outcome of a territorial list based on the hypothetical results for county Pest is shown on the left hand side of Table 2. Pest can distribute a maximum of 14 seats. According to the allocation procedure, the total number of votes has to be divided by the number of seats plus one. Referring to the second column of Table 2, a seat requires $x=[608,500 /(14+1)]=40,566$ votes, where $[x]$ denotes the largest integer 
not greater than $x$. The fourth column (quota) of Table 2 is calculated by dividing the number of votes of the respective party by 40,566. First, every party receives the largest whole number not greater than its quota, thus parties $\mathrm{A}, \mathrm{B}, \mathrm{C}$, and $\mathrm{D}$ receive $[233,000 / 40,566]=5,[45,000 / 40,566]=1,[273,500 / 40,566]=6$, and $[37,000 / 40,566]$ $=0$ seats, respectively. Second, according to the so-called "two-thirds limit" rule, the remaining seats can be allotted to parties with a fractional quota of at least two-thirds, following the procedure of largest remainders. If all seats of a territorial list cannot be allotted by this two-step procedure, then the remaining seats are added to the seats to be distributed on the national list. Turning back to Table 2, the first step already allotted 12 seats, and thus, two additional seats may be allotted. The remainders of parties A, C, and $\mathrm{D}$ pass the two-thirds limit, but since party $\mathrm{C}$ has the smallest of these three remainders, it does not receive an additional seat. The final allotment can be seen in the sixth column of Table 2. Since parties A and D would require $6 * 40,566-233,000=$ 10,396 and $40,566-37,000=3,566$ additional votes, respectively, to obtain their additional seats, these votes will be subtracted from their national list. In addition, party B's votes of $45,000-40,566=4,434$ and party C's votes of $273,500-6 * 40,566=30,104$

Location of Table 2 did not qualify for a seat and, therefore, these votes must be added to those parties' national lists. These values can be found in the fifth column of Table 2 .

One reason for the emergence of the population paradox is the application of the "largest remainder" procedure in allotting the remaining seats. To see this, assume that the ally of party $\mathrm{C}$ (party $\mathrm{D}$ ) received 5,000 votes less, which would have resulted in the outcome shown on the right hand side of Table 2. The quotas of parties $\mathrm{A}, \mathrm{B}$, and $\mathrm{C}$ increase proportionally; however, considering the fractional parts, party $\mathrm{C}$ overtakes party A. The population paradox may be observed by comparing the left hand side of 
Table 2 with the right hand side: party A obtains fewer seats, while only party D's votes decrease and the other parties' votes remain fixed. The problem is even more serious because, on the Pest territorial list, the "informal alliance" of parties C and D gains a seat from the coalition of parties A and B, caused solely by party D obtaining 5,000 fewer votes than before.

As determined for county Pest, the national list is comprised, as already mentioned, of losing SMD votes and correction votes for all territorial lists. One might think that the transfer of seats in Pest would be reversed by the modified correction votes on the national list. Though this type of compensation through the national list is possible, it is not always the case: in 2006, on the national list almost 50,000 votes were needed to obtain a seat, while the same values for the territorial lists ranged from 22,000 to 41,000 . Thus, this type of compensation mechanism is imperfect.

The emergence of a drastic population paradox effect is shown by shifting a seat from the government coalition to the opposition on each territorial list. This is done either by increasing the votes of a coalition party or by decreasing the votes of an opposition party. For example, starting from the outcome shown in Table 3, and emphasizing that the outcome of this hypothetical election assumes almost the same voter participation rate in each county as had been observed in the 2006 election, each

Location of Table 3 county's seats and number of correction votes can be determined in the same way as for county Pest (see also Table 2). ${ }^{3}$

From Table 3, parties A, B, C, and D pass the 5\% threshold; all 152 territorial seats have been allotted. ${ }^{4}$ The coalition of parties A and B obtains 22 territorial seats more than the opposition parties $\mathrm{C}$ and $\mathrm{D}$. To determine the final outcome of the election, the

\footnotetext{
${ }^{3}$ This and all remaining calculations are available at http://www.uni-corvinus.hu/ tasnadi/paradoxon.xls.

${ }^{4}$ The changes in votes and seats for the modified results are written in parenthesis.
} 
58 seats from the national list must be allotted. For simplicity, assume again that "splitticket" voting does not occur, and that the SMD candidates therefore obtain the same number of votes as the nominating party list in the same SMD. Since the assumption is that either party A or party $\mathrm{C}$ wins all SMDs in a county, the parties' SMD losing votes can be determined simply by adding a party's losing territorial list votes. By checking the territorial lists one can verify that the correction votes of parties A, B, C, and D are equal to $-162,376,127,610,313,538$ and 232,428 , respectively. Table 4 contains the values needed for the allotment of the 58 national seats. According to the election system, these 58 seats must be distributed based on the aggregate of the lost SMD votes and territorial correction votes according to D'Hondt's procedure, which is equivalent to

Location of Table 4

Jefferson's procedure. ${ }^{5}$ Thus, one can obtain the allotment on the left hand side of Table 4 by employing, for instance, 53,000 as the common divisor.

Adding the SMD, the territorial, and the national seats, parties A, B, C, and D receive $185,14,175$, and 12 seats, respectively. Thus, the coalition of parties A and B can form a government with a majority of 12 seats.

The results of Table 3 in each county can be slightly modified either by increasing party A's or party B's votes, or by decreasing party C's or party D's votes. The respective changes in votes and seats can be found in parenthesis. According to the modified results determined by Table 3, parties A, B, C, and D pass the 5\% threshold, and the coalition of parties A and B obtains 18 territorial seats less than the opposition comprised of parties C and D. Now, turning to the national list, the values at the right

\footnotetext{
${ }^{5}$ D'Hondt's procedure allocates the seats successively by giving the next seat to the party with the largest obtained votes per obtained seats plus one ratio. Jefferson's procedure determines a common divisor (for instance, by a trial-and-error method) so that the sum of the whole numbers contained in the votes of a party per the common divisor equals the total number of seats.
} 
hand side of Table 4 determine the allotment of the 58 national seats. Once again, the common divisor of 53,000 provides the allotment.

Aggregating the SMD, the territorial, and the national allotments, parties $\mathrm{A}, \mathrm{B}, \mathrm{C}$, and $\mathrm{D}$ receive $178,14,181$, and 13 seats, respectively. Now the coalition of parties A and B loses the election by a difference of 2 seats. Summarizing the results, a transfer of seven seats is possible from parties $\mathrm{A}$ and $\mathrm{B}$ to parties $\mathrm{C}$ and $\mathrm{D}$ in this paradoxical way.

The effect of the population paradox can even be enlarged to a transfer of 8 seats by a slight modification of the lost SMD votes on the national list, which requires "splitticket" voting. Assume that 25,500 voters, who voted for party D, vote for the SMD candidates of party $\mathrm{C}$ in SMDs won by party A. Thus, shift 25,500 votes on the national list from party $\mathrm{D}$ to party $\mathrm{C}$. In addition, assume that 9,360 voters of party A vote for party B's candidates in SMDs lost by party A's candidates and that 18,720 voters of party B vote for party A's candidates in SMDs won by party A's candidates. This modification decreases the votes on the national lists of parties A and B by 9,360 each.

Location of Table 5 Based on the territorial results of Table 3, the new allotment shown in Table 5 is calculated by applying the common divisor 52,500 .

Aggregating the results of Tables 3 and 5, the coalition comprised of parties A and B again wins the election by 12 seats. Now, combining the above-described "split-ticket" voting with the modified territorial results of Table 3, the allotment of the 58 seats of the national list is shown on the right hand side of Table 5. By comparing the right hand sides of Tables 4 and 5, there is a shift of an additional seat from the coalition of parties $\mathrm{A}$ and $\mathrm{B}$ to parties $\mathrm{C}$ and $\mathrm{D}$, and the coalition of parties $\mathrm{A}$ and $\mathrm{B}$ loses the election by 4 seats. Thus, it is possible to shift as many as 8 seats from one side to the other in this paradoxical way. 


\section{The cause of the population paradox}

As noted, one reason for the emergence of the population paradox in the Hungarian electoral system is the application of the method of largest remainders in the so-called "two-thirds limit" rule. Without the territorial correction votes, the effect of the population paradox would be even larger, since a seat could be lost on each territorial list, thus transferring 20 seats in this paradoxical way. Hence, the national list dampens the effect of the population paradox but does not eliminate it. The compensation mechanism would be perfect if the "price" of a seat in votes were the same on each territorial list and on the national list.

The paradox in Section 3 might seem like a purely constructed example, which would rarely occur in an actual election. However, the population paradox did in fact occur in the 2006 election. To verify this, the actual outcome of the 2006 election can be compared with the case in which the smallest governing party (SZDSZ) receives 4,000 votes less in Győr-Moson-Sopron and 7,400 votes less in Szabolcs-Szatmár-Bereg, while the smallest opposition party (MDF) receives 1,200 votes more in Baranya and 9,000 votes more in Somogy. This "slight" modification would transfer one seat from the largest opposition party (FIDESZ) to the largest governing party (MSZP) in this paradoxical way. Though this would not have altered the final outcome of the election, it points to the existence of the paradox in actual elections.

So far, the issue of whether the first votes (i.e. the SMD votes) could contribute to the population paradox has not been explored. Clearly, a unilateral increase in first votes cannot lead to a paradoxical seat transfer if it does not change the winner of the SMD election. However, if the winner of a SMD changes by a unilateral increase in votes, 
first votes can also contribute to the population paradox. A simple example can illustrate this, bearing in mind that redistricting has never occurred in the new Hungarian democracy, and therefore there were SMDs ranging from 30,000 to 67,000 voters in 2006. As noted above, the price, in votes, of a seat on the national list in 2006 was slightly less than 50,000. Suppose that there are several SMDs with 60,000 participating voters, with just two candidates, and the candidates nominated by party A win by a margin of just a few votes over the candidates nominated by party C. Now if each of the party $\mathrm{C}$ candidates receives a few additional votes, turning around the outcome of its SMD, then it could happen that party $\mathrm{C}$ loses more seats on the national list than are gained by the newly won SMDs, since party $\mathrm{C}$ loses slightly less than 30,000 votes on the national list, while party A gains slightly more than 30,000 votes on the national list. This situation did not occur in 2006 , since only about 45,000 voters cast ballots in the largest SMD. Nonetheless, this type of paradox could occur in the future if no redistricting happens for many years, or if the participation rates become too heterogeneous.

The first and the second votes both are subject to the population paradox. The lesson for electoral system designers is that in the case of national lists being used for dampening the outcomes in the SMDs, the ratio of SMD seats to the number of seats on the national list has to be chosen carefully, and redistricting has to be done regularly. ${ }^{6}$ Moreover, it is well-established that the method of largest remainders should be avoided in any form, especially if PR formulas are used separately for each territorial list.

There are many ways to avoid the population paradox even in mixed electoral systems. To meet the original objective of the designers of the Hungarian electoral

\footnotetext{
${ }^{6}$ However, redistricting can cause other problems, such as gerrymandering.
} 
system (namely, to include SMDs, ensure smaller parties' presence in Parliament by PR, compensate for the winner-take-all effect of SMDs, have small territories, and have territorial representation both in the SMD and PR branch), one suggestion, for instance, could be that the national list should only be used for the compensation of SMDs, and a bi-proportional allocation procedure could be used for the allocation of the 152 territorial seats. $^{7}$

\section{Concluding remarks}

The population paradox represents an important flaw in the Hungarian electoral system because a party's additional voters or its opponents' absent voters can lead to a loss in that party's number of representatives in a territory, with the election results thus not reflecting the will of voters. To put it into a dynamic context, consider the following possible chronology of an election day: an hour before polls are closing, some voters think about staying away because of, say, good weather. In that case, with the population paradox, conscientious supporters can harm their preferred party, while an opponent can benefit from having lazier supporters. Clearly, this type of paradox is not desirable in an electoral system.

In the Hungarian electoral system, it is possible to shift 8 seats from one side (coalition or opposition) to the other side in this paradoxical way. This is demonstrated using recent participation rates and party structure. Assuming a different party structure, with more parties passing the $5 \%$ threshold, it would be possible to increase the extent

\footnotetext{
${ }^{7}$ The bi-proportional allocation procedure was developed by Balinski and Demange (1989) and first implemented by Pukelsheim and Schuhmacher (2004) for the municipal elections 2006 in Zürich.
} 
of the population paradox, since this could lead to an increase in the number of SMDs losing votes and thus, in the relative difference between the value of a territorial vote on the territorial lists and on the national list.

\section{Acknowledgements}

The author would like to thank Trenton G. Smith, the Editor in Chief, and two anonymous referees for their helpful comments and suggestions. The financial support from the Hungarian Academy of Sciences (MTA) through the Bolyai János research fellowship is gratefully acknowledged.

\section{References}

Altunbas, Y. \& Chakravarty, S.P. (2000). Proportional representation in the Welsh Assembly. Public Choice 103, 85-94.

Altunbas, Y., Chakravarty, S.P. \& Steffen, F. (2002). A note on the electoral rules for the Welsh Assembly. Public Choice 111, 185-193.

Balinski, M.L. \& Demange, G. (1989). An axiomatic approach to proportionality between matrices. Mathematics of Operations Research 14, 700-719.

Balinski, M.L. \& Young, H.P. (2001). Fair Representation: meeting the ideal of one man, one vote (second edition). (Washington D.C.: Brookings Institution Press) 
Benoit, K. (2001). Evaluating Hungary's Mixed-Member Electoral System. (In M. Søberg Shugart \& M.P. Wattenberg (Eds.), Mixed-Member Electoral Systems: The Best of Both Worlds? (pp. 477-494). Oxford: Oxford University Press.)

Benoit, K. \& Schiemann, J.W. (2001). Institutional Choice in New Democracies: Bargaining Over Hungary's 1989 Electoral Law. Journal of Theoretical Politics 13, 159-188.

Fehndrich, M. (1999). Paradoxien des Bundestags-Wahlsystems. Spektrum der Wissenschaft 99, 70-73.

Pukelsheim, F. \&and Schuhmacher, C. (2004). Das neue Zürcher Zuteilungsverfahren für Parlamentswahlen. Aktuelle Juristische Praxis - Pratique Juridique Actuelle 13, $505-522$.

Tasnádi, A. (2007). Statikus elosztások jellemzése. Köz-Gazdaság, 2, 103-125. 


\section{Tables}

Table 1. Seat distributions by counties

\begin{tabular}{l|cc}
\hline Counties & SMDs & Territorial seats \\
\hline Budapest & 32 & 28 \\
Baranya & 7 & 6 \\
Bács-Kiskun & 10 & 8 \\
Békés & 7 & 6 \\
Borsod-Abaúj-Zemplén & 13 & 11 \\
Csongrád & 7 & 6 \\
Fejér & 7 & 6 \\
Győr-Moson-Sopron & 7 & 6 \\
Hajdú-Bihar & 9 & 8 \\
Heves & 6 & 5 \\
Jász-Nagykun-Szolnok & 8 & 6 \\
Komárom-Esztergom & 5 & 5 \\
Nográd & 4 & 4 \\
Pest & 16 & 14 \\
Somogy & 6 & 5 \\
Szabolcs-Szatmár-Bereg & 10 & 9 \\
Tolna & 5 & 4 \\
Vas & 5 & 4 \\
Veszprém & 7 & 6 \\
Zala & 5 & 5 \\
\hline Sum & 176 & 152 \\
\hline
\end{tabular}

Table 2. Results for county Pest

\begin{tabular}{|c|c|c|c|c|c|c|c|c|c|c|}
\hline \multirow[b]{2}{*}{ Party } & \multicolumn{5}{|c|}{ original results } & \multicolumn{5}{|c|}{ modified results } \\
\hline & votes & $\%$ & quota & correction & seats & $\begin{array}{l}\text { change } \\
\text { in votes }\end{array}$ & $\%$ & quota & $\begin{array}{c}\text { Correc- } \\
\text { tion }\end{array}$ & seats \\
\hline A & 233,000 & 38.3 & 5.744 & $-10,396$ & 6 & & 38.6 & 5.791 & 31,835 & 5 \\
\hline B & 45,000 & 7.4 & 1.109 & 4,434 & 1 & & 7.5 & 1.119 & 4,767 & 1 \\
\hline C & 273,500 & 44.9 & 6.742 & 30,104 & 6 & & 45.3 & 6.798 & $-8,131$ & 7 \\
\hline D & 37,000 & 6.1 & 0.912 & $-3,566$ & 1 & $-5,000$ & 5.3 & 0.795 & $-8,233$ & 1 \\
\hline \multirow[t]{2}{*}{ Others } & 20,000 & 3.3 & 0.493 & & & & 3.3 & 0.497 & & \\
\hline & 608,500 & 100.0 & 15.000 & & 14 & & 100.0 & 15.000 & & 14 \\
\hline
\end{tabular}


Table 3. Territorial lists

\begin{tabular}{|c|c|c|c|c|c|c|c|c|c|c|}
\hline \multirow[b]{2}{*}{ Counties } & \multicolumn{2}{|l|}{$A$} & \multicolumn{2}{|l|}{$B$} & \multicolumn{2}{|l|}{$C$} & \multicolumn{2}{|c|}{$D$} & \multicolumn{2}{|c|}{ Others } \\
\hline & votes & seats & votes & seats & votes & seats & votes & seats & votes & seats \\
\hline Budapest & $\begin{array}{r}460,000 \\
(+10,000)\end{array}$ & 13 & 133,800 & $\begin{array}{r}4 \\
(-1)\end{array}$ & 356,000 & 10 & 61,300 & $\begin{array}{r}1 \\
(+1)\end{array}$ & 36,000 & 0 \\
\hline Baranya & 123,000 & $\begin{array}{r}4 \\
(-1)\end{array}$ & $\begin{array}{r}8,000 \\
(+1,500)\end{array}$ & 0 & 90,000 & $\begin{array}{r}2 \\
(+1)\end{array}$ & 8,000 & 0 & 1,500 & 0 \\
\hline Bács-Kiskun & 121,100 & $\begin{array}{r}4 \\
(-1)\end{array}$ & 8,000 & 0 & 154,000 & $\begin{array}{r}4 \\
(+1)\end{array}$ & $\begin{array}{r}11,800 \\
(-3,800)\end{array}$ & 0 & 2,000 & 0 \\
\hline Békés & 80,500 & $\begin{array}{r}3 \\
(-1)\end{array}$ & 7,000 & 0 & 110,500 & $\begin{array}{r}3 \\
(+1)\end{array}$ & $\begin{array}{r}10,500 \\
(-1,500)\end{array}$ & 0 & 2,000 & 0 \\
\hline Borsod-A.-Z. & 209,000 & $\begin{array}{r}7 \\
(-1)\end{array}$ & $\begin{array}{r}9,000 \\
(+1,000)\end{array}$ & 0 & 146,500 & $\begin{array}{r}4 \\
(+1)\end{array}$ & 9,000 & 0 & 1,000 & 0 \\
\hline Csongrád & 116,000 & $\begin{array}{r}4 \\
(-1)\end{array}$ & $\begin{array}{r}9,000 \\
(+1,100)\end{array}$ & 0 & 84,500 & $\begin{array}{r}2 \\
(+1)\end{array}$ & 9,000 & 0 & 1,000 & 0 \\
\hline Fejér & 80,500 & $\begin{array}{r}3 \\
(-1)\end{array}$ & 7,000 & 0 & 110,500 & $\begin{array}{r}3 \\
(+1)\end{array}$ & $\begin{array}{r}10,500 \\
(-1,500)\end{array}$ & 0 & 2,000 & 0 \\
\hline Győr-M.-S. & 94,600 & $\begin{array}{r}3 \\
(-1)\end{array}$ & 10,000 & 0 & 130,000 & $\begin{array}{r}3 \\
(+1)\end{array}$ & $\begin{array}{r}12,600 \\
(-1,600)\end{array}$ & 0 & 1,000 & 0 \\
\hline Hajdú-Bihar & 115,500 & $\begin{array}{r}4 \\
(-1)\end{array}$ & 9,000 & 0 & 146,900 & $\begin{array}{r}4 \\
(+1)\end{array}$ & $\begin{array}{r}10,800 \\
(-800)\end{array}$ & 0 & 1,000 & 0 \\
\hline Heves & 100,000 & $\begin{array}{r}4 \\
(-1)\end{array}$ & $\begin{array}{r}6,500 \\
(+1,500)\end{array}$ & 0 & 46,500 & $\begin{array}{r}1 \\
(+1)\end{array}$ & 5,500 & 0 & 1,000 & 0 \\
\hline Jász-N.-Sz. & 116,000 & $\begin{array}{r}4 \\
(-1)\end{array}$ & $\begin{array}{r}9,000 \\
(+1,100)\end{array}$ & 0 & 84,500 & $\begin{array}{r}2 \\
(+1)\end{array}$ & 9,000 & 0 & 1,000 & 0 \\
\hline Komárom-E. & 100,000 & $\begin{array}{r}4 \\
(-1)\end{array}$ & $\begin{array}{r}6,500 \\
(+1,500)\end{array}$ & 0 & 46,500 & $\begin{array}{r}1 \\
(+1)\end{array}$ & 5,500 & 0 & 1,000 & 0 \\
\hline Nográd & 37,600 & $\begin{array}{r}2 \\
(-1)\end{array}$ & $\begin{array}{r}8,000 \\
(+2,000)\end{array}$ & 0 & 40,000 & 2 & 16,000 & $\begin{array}{r}0 \\
(+1)\end{array}$ & 5,500 & 0 \\
\hline Pest & 233,000 & $\begin{array}{r}6 \\
(-1)\end{array}$ & 45,000 & 1 & 273,500 & $\begin{array}{r}6 \\
(+1)\end{array}$ & $\begin{array}{r}37,000 \\
(-5,000)\end{array}$ & 1 & 20,000 & 0 \\
\hline Somogy & 50,000 & $\begin{array}{r}2 \\
(-1)\end{array}$ & 7,000 & 0 & 107,100 & $\begin{array}{r}3 \\
(+1)\end{array}$ & $\begin{array}{r}11,000 \\
(-5,000)\end{array}$ & 0 & 1,000 & 0 \\
\hline Szab.-Sz.-B. & 136,000 & $\begin{array}{r}5 \\
(-1)\end{array}$ & $\begin{array}{r}10,000 \\
(+2,000)\end{array}$ & 0 & 120,000 & 4 & 20,000 & $\begin{array}{r}0 \\
(+1)\end{array}$ & 3,000 & 0 \\
\hline Tolna & 45,120 & $\begin{array}{r}2 \\
(-1)\end{array}$ & $\begin{array}{r}9,600 \\
(+2,400)\end{array}$ & 0 & 48,000 & 2 & 19,200 & $\begin{array}{r}0 \\
(+1)\end{array}$ & 6,600 & 0 \\
\hline Vas & 52,640 & $\begin{array}{r}2 \\
(-1)\end{array}$ & $\begin{array}{r}11,200 \\
(2,210)\end{array}$ & 0 & 56,000 & 2 & 22,400 & $\begin{array}{r}0 \\
(+1)\end{array}$ & 7,700 & 0 \\
\hline Veszprém & 78,800 & $\begin{array}{r}3 \\
(-1)\end{array}$ & 8,000 & 0 & 108,000 & $\begin{array}{r}3 \\
(+1)\end{array}$ & $\begin{array}{r}9,500 \\
(-2,000)\end{array}$ & 0 & 2,000 & 0 \\
\hline Zala & 60,000 & 2 & 18,700 & $\begin{array}{r}1 \\
(-1) \\
\end{array}$ & 74,000 & $\begin{array}{r}2 \\
(+1) \\
\end{array}$ & $\begin{array}{r}10,500 \\
(-500) \\
\end{array}$ & 0 & 3,000 & 0 \\
\hline Sum & $\begin{array}{l}2,409,360 \\
(+10,000)\end{array}$ & $\begin{array}{r}81 \\
(-18) \\
\end{array}$ & $\begin{array}{r}340,300 \\
(+16,310)\end{array}$ & $\begin{array}{r}6 \\
(-2)\end{array}$ & $2,333,000$ & $\begin{array}{r}63 \\
(+15)\end{array}$ & $\begin{array}{r}309,100 \\
(-21,700)\end{array}$ & $\begin{array}{r}2 \\
(+5)\end{array}$ & 99,300 & 0 \\
\hline
\end{tabular}


Table 4. National list

\begin{tabular}{l|rrrrr|rrrrr}
\hline \multirow{2}{*}{ Party } & \multicolumn{5}{|c|}{ original results } & \multicolumn{4}{c}{ modified results } \\
\cline { 2 - 11 } & $\begin{array}{c}\text { SMD } \\
\text { votes }\end{array}$ & correction & Sum & $\%$ & seats & $\begin{array}{c}\text { change } \\
\text { in SMD }\end{array}$ & correction & sum & $\%$ & seats \\
\hline A & $1,049,360$ & $-162,376$ & 886,984 & 27.9 & 16 & 0 & 388,413 & $1,437,773$ & 45.3 & 27 \\
B & 340,300 & 127,610 & 467,910 & 14.7 & 8 & 16,310 & 207,024 & 563,634 & 17.7 & 10 \\
C & 974,500 & 313,538 & $1,288,038$ & 40.4 & 24 & 0 & $-151,841$ & 822,659 & 25.9 & 15 \\
D & 309,100 & 232,428 & 541,528 & 17.0 & 10 & $-21,700$ & 66,731 & 354,131 & 11.1 & 6 \\
\hline Sum & $2,673,260$ & 511,200 & $3,184,460$ & 100 & 58 & $-5,390$ & 510,327 & $3,178,197$ & 100 & 58 \\
\hline
\end{tabular}

Table 5. "Split-ticket" voting

\begin{tabular}{l|rrrrr|rrrrr}
\hline \multirow{2}{*}{ Party } & \multicolumn{5}{|c|}{ original results } & \multicolumn{4}{c}{ modified results } \\
\cline { 2 - 11 } & \multicolumn{1}{|c}{ SMD } & correction & sum & $\%$ & seats & $\begin{array}{c}\text { change } \\
\text { in SMD }\end{array}$ & correction & sum & $\%$ & seats \\
\hline A & $1,040,000$ & $-162,376$ & 877,624 & 27.7 & 16 & 0 & 388,413 & $1,428,413$ & 45.2 & 26 \\
B & 330,940 & 127,610 & 458,550 & 14.5 & 8 & 16,310 & 207,024 & 554,274 & 17.5 & 10 \\
C & $1,000,000$ & 313,538 & $1,313,538$ & 41.5 & 25 & 0 & $-151,841$ & 848,159 & 26.9 & 16 \\
D & 283,600 & 232,428 & 516,028 & 16.3 & 9 & $-21,700$ & 66,731 & 328,631 & 10.4 & 6 \\
\hline Sum & $2,654,540$ & 511,200 & $3,165,740$ & 100 & 58 & $-5,390$ & 510,327 & $3,159,477$ & 100 & 58 \\
\hline
\end{tabular}

